\title{
Feasibility Study of Irrigation Development for Sustainable Natural Resources Management Under Changing Climate of Jabi Tehnan Woreda, Amhara Regional State of Ethiopia
}

\author{
Ashebir Haile Tefera \\ Irrigation and Drainage Research Department, Ethiopian Institute of Agricultural Research (EIAR), Debre Zeit Agricultural Research Centre, \\ Debre Zeit, Ethiopia
}

Email address:

ashu_haile@yahoo.com, haileashebir@gmail.com

\section{To cite this article:}

Ashebir Haile Tefera. Feasibility Study of Irrigation Development for Sustainable Natural Resources Management Under Changing Climate of Jabi Tehnan Woreda, Amhara Regional State of Ethiopia. American Journal of Environmental and Resource Economics.

Vol. 6, No. 2, 2021, pp. 29-39. doi: 10.11648/j.ajere.20210602.11

Received: March 29, 2021; Accepted: April 27, 2021; Published: May 31, 2021

\begin{abstract}
Irrigation development has been identified as one of the priority investment sectors in Ethiopia and the government has been implementing a number of efforts that enhance the planning and implementation of small-scale irrigation projects in the country. The aim was to identify the potential, feasibility and profitability of irrigation development for spices production mainly pepper in Jabi woreda of West-Gojjam, Amhara region. It has been observed that majority of the population, live in the rural area with crop production as the main livelihood option, arable land constitutes the largest portion of the 'woreda' land use type with cultivated land accounting for 49.8\% (58,262 ha), uncultivable land 4.4\% or 5,208 ha, natural forest $5.5 \%$ or 6,502 ha, bush land /scrubland and or natural pasture accounts $17.6 \%$ or 20,662 ha, settlement $9.3 \%$ or 10,931 ha and others account $13 \%$ or 15,389 ha. The altitude varies from 1400 to $2300 \mathrm{~m}$ a.s.l. This woreda is mostly characterized by Haplic Nitisols soil type which is highly productive type of soil in Ethiopia. In most of the fields, the slope gradient ranges from $0 \%$ to $5 \%$. The project was studied to irrigate the command area through gravity close pipe conveyance system of surface irrigation with head work of wire division from Lah River. It was studied that about 45,595 ha is suitable irrigable land for surface irrigation of which about 45\% (20,105 ha) of suitable land under Lah rive. An agronomic cropping pattern and production calendar of the farming system had identified for the sustainable supply of raw material for the agro-processing plant. Therefore, in the dry season using full irrigation 200ha pepper, 40ha rosemary and 10ha moringa had been under production whereas under rainfed with supplemental irrigation chickpea and field pea 130ha, white and black cumin 40ha and garlic 30ha was produced. The total investment cost of the project was estimated about ETH Birr 48.1 million. The implementation of the proposed irrigation project would require diversion of Lah River and $0.365 \mathrm{~m}^{3} / \mathrm{sec}$ of water was diverted from the river to the project command area. The minimum flow of the Lah River was $1.99 \mathrm{~m}^{3} / \mathrm{sec}$ at $95 \%$ probability. Thus, downstream impact of abstraction by the project was insignificant. Therefore, it could be concluded that there was no severe or immitigable impacts that could prevent the implementation of the proposed irrigation development.
\end{abstract}

Keywords: Feasibility, Crop Pattern, Downstream, Development and Smallholder

\section{Introduction}

Unreliable rainfall, recurrent drought and limited use of the available water resources, coupled with heavy reliance on rain-fed subsistence agriculture, have contributed adversely to the economy of Ethiopia. In fact, the World Bank [37] estimates that unmitigated hydrological variability currently costs the economy over one-third of its growth potential and leads to 25 percent increase in poverty rates. Hence, enhancing public and private investment in irrigation development has been identified as one of the core strategies aimed to de-link economic performance from rainfall and to enable sustainable growth and development $[37,27]$. In the government policy documents, irrigation development is identified as an important tool to stimulate sustainable economic growth and rural development and is considered as 
a corner stone of food security and poverty reduction $[29,28]$.

Irrigation development has been identified as one of the priority investment sectors in Ethiopia and the government has been implementing a number of efforts that enhance the planning and implementation of small-scale irrigation projects in the country $[1,17]$. It is understood that the principal objective of the project, within the framework of alleviating the chronic problem of food shortage through the efficient utilization of the enormous land and water resources, is to develop irrigation projects at West-Gojjam (Bure, JabiTehnan, Womberima and Dembecha) aimed at improving the livelihood of the project beneficiaries and related benefitting stakeholders. These areas are spices potential and producing areas mainly Red Pepper in Ethiopia though maize and wheat are major crops produced from cereals in the areas.

Jabi-Tehnan woreda of around Finote Selam city is high potential area of producing spices especially pepper as a major commodity next to womberima though there is high potential of irrigable land in this woreda, there is no experience of farmers producing red pepper under mechanized and irrigation. More than 6,153 ha of land covered and more than 18,900 households are producing red pepper in the area and this figure doesn't included the area which is under cultivation of private investor [19]. The average productivity is $2 \mathrm{t} / \mathrm{ha}$. This woreda has high potential areas

Spice crops are produced in various regions of the country and predominantly by smallholder farmers as a cash crop traded primarily in domestic markets, but with increasing success also entering foreign markets. The spice sub-sector has an immense potential for economic development and poverty reduction through creation and expansion of employment opportunities and distribution of income and foreign exchange earnings [21]. However, except pepper (Capsicum annum), spice crops cultivation is traditional, with no or very little research and extension support. Furthermore, the status of spice production and marketing in the country is not well documented. Currently, there is a growing demand for organic spices in Europe, USA and Japan for food coloring, cosmetics, pharmaceuticals, essential oil derivatives and textile industries. The majority of spices produced in Ethiopia $(80 \%)$ are consumed domestically. But at the same time, export of spices is developing, which fetches increased foreign exchange earnings. Ethiopia exports specifically ginger and turmeric in the whole form even if importers prefer ginger to come in sliced form [21]. Ethiopia also exports, to a limited extent, extracts of ginger, hot pepper and turmeric to Europe for food coloring and flavoring [36]. Farmers use irrigation mainly for Capsicum. They irrigate Capsicum every week up to the time the crop sets pods. Capsicum demands high irrigation frequency during transplanting, flowering and pod setting periods. Irrigation should be terminated during January to avoid frost damage $[35,36]$.

In Ethiopia, the cultivation practices being practiced by smallholder farmers is not improved and the technique is highly based on the knowledge that passed from generations and as a result production level is low. Except pepper (Capsicum annum) spices cultivation practices are traditional and no improved seed or planting material is available in Ethiopia [1, 36]. According to [18], limited production technologies developed for spices so far have yet not multiplied and popularized to farmers. Disease like: fusarium wilt, blight, powdery mildew, downy mildew, leaf spot, root rot, damping-off, rust, stem gal, grain mold, and pests such as aphids, mites, stick-bugs, leaf eating caterpillars are also constraints that led to overall reduction in productivity and quality of spices in Ethiopia. Moreover, [11] also reported a high frequency of weeding, high input need, different diseases and pests, wild animal competition are some of the constraints affecting production of spices in Ethiopia.

\section{Objectives}

1. To identify suitable irrigation type and of farmers experience in the study area.

2. To identify soil type, landscape, source of water for irrigation.

3. To determine the agronomic management for the selected commodities.

4. To determine the water demands for the irrigation development project in the study area.

\section{Methodology}

The feasibility study of the project was conducted based on primary and secondary data collected on topography, geology, soils, climate and hydrology, irrigation agronomy, socio-economy, environment, and catchment management etc..,. An intensive field investigate on with regard to topographic \& soil characteristics; land and water resources \& climatic factors; cropping \& agronomic practices; as well as infrastructure and other environmental related assessment was conducted. Consequently, key technical and environmental issues have been identified under major potential woreda for analysis and planning purposes.

\subsection{Project Location and Sites}

The Jabi-Tehnan woreda is located in West Gojjam Zone of Amhara Regional State of Ethiopia. This woreda surrounds the Finote Selam town which is the capital city of West Gojjam Zone of Amhara Region, 285km from the capital Addis Ababa and $170 \mathrm{~km}$ from Bahir Dar. This woreda has a coordinates of Longitude $37^{\circ} 00^{\prime} 00^{\prime \prime}$ to $37^{\circ} 40^{\prime} 00^{\prime \prime}$ and Latitude $10^{\circ} 30^{\prime} 00^{\prime \prime}$ to $10^{\circ} 50^{\prime} 00^{\prime \prime}$ with an elevation ranges from 1400 to 2300 meters above sea level. The majority of the area lies in the higher altitude range closer to 2,300 thus making the area to be dominated by mid-altitude area and according to the traditional classification of agro-ecology $88 \%$ of it is grouped under Woyina Dega and the remaining 12\% classified as 'kolla'.

The total area of the Woreda is estimated to be $1,169.54 \mathrm{~km}^{2}$ or 116,954 ha. (Source: woreda office of agriculture). The district divided into 37 rural kebeles. The total population of the district in 2008 was estimated to be 277,590 / of which 
139,616 are male and 137, 9974 female (Source woreda plan and economy). The district has 37 rural kebeles and 2 urban kebeles. Majority or $94 \%$ of the population i.e. 259,855 live in rural area and the remaining $6 \%$ that accounts about 17,724 live in urban area. Hence, this woreda is selected as a project area because it has a high potential area of producing spices especially pepper as a major commodity next to womberima though there is high potential of irrigable land in this woreda, there is no experience of farmers producing red pepper under mechanized and irrigation.
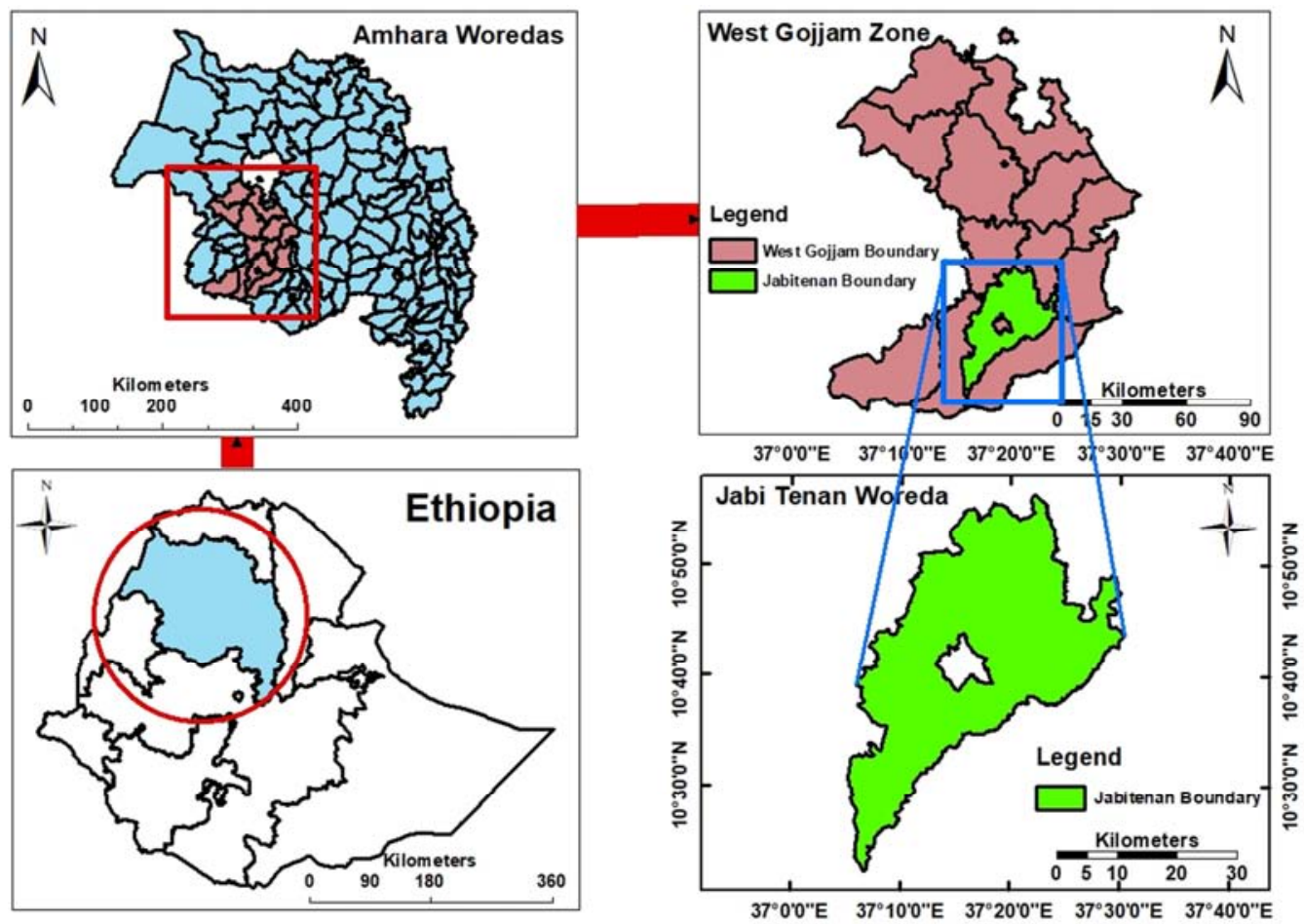

Figure 1. Location map of project site.

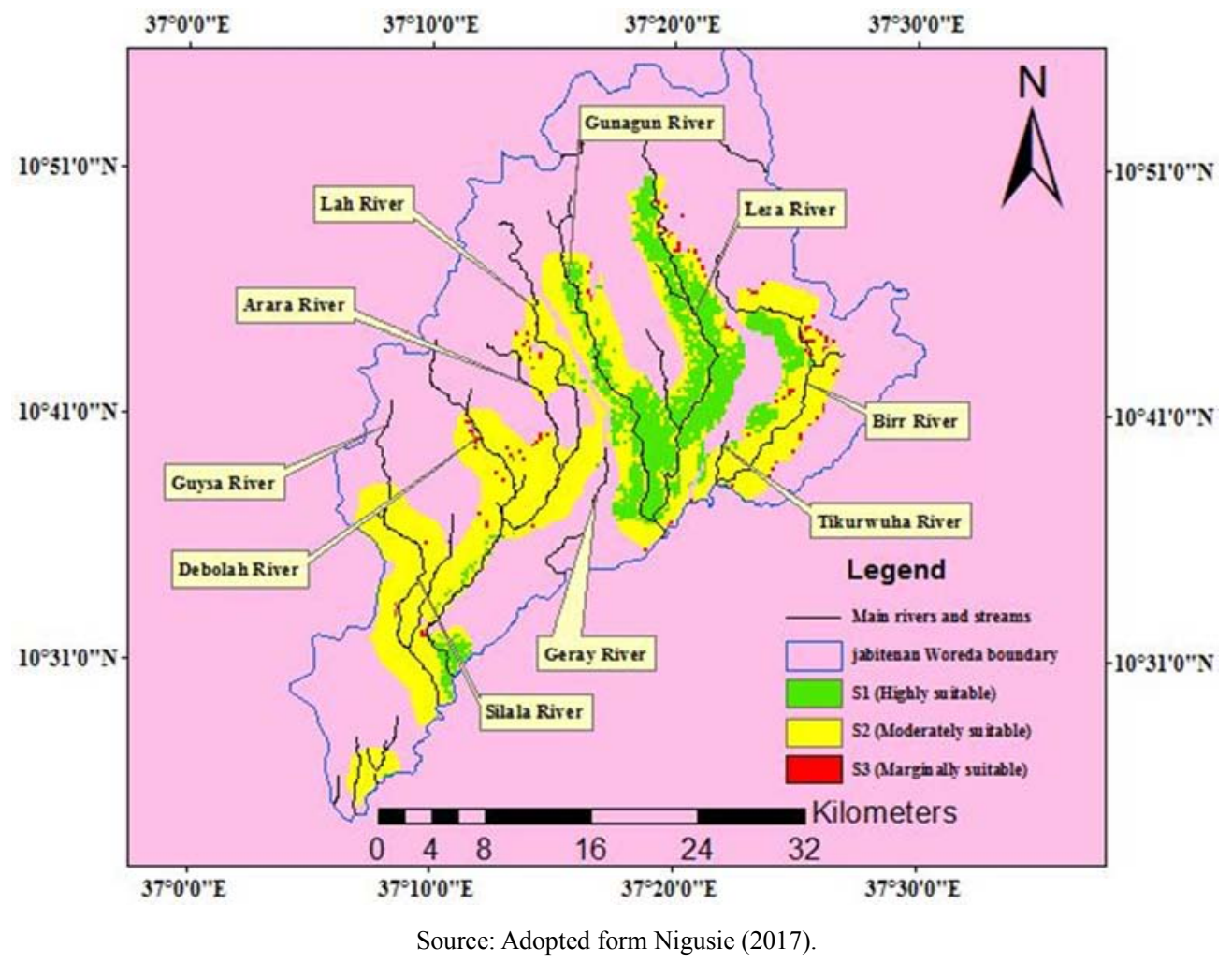

Figure 2. Existing surface water sources and their suitability. 


\subsection{Water Resources of the Project Area}

Jabi Tehnan woreda is a high potential for surface water. There are many perennial rivers such as Lah, Geray, Silala, Debolah, Birr, Leza, Tikur wuha, Gunagun, Arara, and Guysa. Despite this large number of rivers, exploitation of their water resources for irrigated agriculture is low in the woreda due to that the water resources of some rivers are not known and potential irrigable areas are not exactly identified Woreda But the study conducted by [30] there are about 45,595 ha is suitable irrigable land for surface irrigation of which about $45 \%(20,105 \mathrm{ha})$ of suitable land under Lah river and its tributaries in the woreda.

Therefore, water source for the project area is Lah River. This River is a perennial which flows over year. This river is one of the gudged one the catchment. Its gudging station is at nearby Finote Selam town. After analysis of 20 years hydrological flow, the maximum mean annual flow was recorded in August $\left(11.38 \mathrm{~m}^{3} / \mathrm{s}\right)$ and minimum flow was recorded in March $\left(1.99 \mathrm{~m}^{3} / \mathrm{s}\right)$.

\subsection{Soil Resources and Investigation}

Agricultural production through adoption of irrigation for the development of agriculture and livestock development should be based on physical resource assessment aimed at sustainable resources utilization. Soil, among others, is a land resource that influences crop suitability and choice of land utilization types; hence every irrigation project should be accompanied by a soil study $[31 ; 10 ; 32]$. Such soil studies will ensure selection of suitable land and planning management practices. The soils investigation of Jabi woreda has been conducted for the purpose of irrigation development at detailed level. All the required parameters under physical \& chemical assessment have been assessed through the methods and methodologies of soil investigation processes as per the [14]. Previous study of a broad soil survey, for the whole of the country, had been carried out by Land Use Planning and Regulatory Department (LUPRD) as part of a resource study for master land use planning of the country [2002; 2010]; it is one of the basic soil resource studies that have been conducted at national level. The study provides mapping of soils and their utilization at 1: 1,000,000 scale. The study was based on interpretation of satellite images and subsequent field checking [19]. This study classified and mapped soils of the entire country mainly based on climate and geo-morphological characteristics. This study had identified landscape units based on a land system approach. The landscape units were subdivided into land facet and each facet was described and classified according to the FAO 1974 soil classification system. According to this study, four soil types Nitosols and Vertisol have been identified in the project area.

\section{Climate and Hydrology}

\subsection{Climatic Features}

The objective of the investigations of this topic was to establish and quantify climatological and hydrological aspects of the study region and derive parameters and hydro meteorological series required for dimensioning, design and evaluation of the Irrigation development project. The climate is tropical with a seasonal wet and dry season. The climate is further moderated by the altitude.

From the analysis of long-term annual rainfall distribution [4], it has been seen most clearly in the two distinct rainy periods which are observed in the northerly plains of the Blue Nile basin. Moving northwards, the more prolonged exposure to the moist air stream is evident in the tendency for the two dominant rainy periods to merge into a more contiguous distribution, culminating in the distribution observed on the highland plateau bordering the south of the basin. The hills to the south-east of the basin still display two rainfall peaks separated by a period of lower rainfall but on the plateau to the west, around Addis Ababa, the distribution shows a continual increase from the spring rains to the summer peak rainfall. The hills extending northwards and forming the western boundary of the basin display the bi-modal distribution of the lower plains. The distribution of rainfall over the highland areas tends to be modified by orographic effects. Bure rainfall station is selected to represent the project area because of geographical proximity and altitude similarity. It is located at coordinate of $8.28^{\circ} \mathrm{N}$ and $35.10^{\circ} \mathrm{E}$ which is found within the project area. The summary of monthly rainfall total aggregated from daily rainfall data is shown in table 1 .

Table 1. Long term climatic data of the study area (ETo).

\begin{tabular}{|c|c|c|c|c|c|c|c|c|c|}
\hline \multirow{2}{*}{ Month } & Min Temp & Max Temp & Humidity & Wind & Sunshine & Radiation & Rain & Eff. rain & ETo \\
\hline & ${ }^{\circ} \mathrm{C}$ & ${ }^{\circ} \mathrm{C}$ & $\mathbf{k P a}$ & km/day & hours & $\mathrm{MJ} / \mathrm{m}^{2} / \mathrm{day}$ & $\mathbf{m m}$ & $\mathbf{m m}$ & mm/day \\
\hline January & 14.6 & 28.7 & 1.72 & 130 & 7.9 & 19.4 & 7 & 0 & 4.01 \\
\hline February & 15.3 & 32.3 & 1.67 & 138 & 7.6 & 20.1 & 28 & 6.8 & 4.49 \\
\hline March & 16.1 & 30.2 & 1.76 & 147 & 6.4 & 19.2 & 70 & 32 & 4.53 \\
\hline April & 16.1 & 29.5 & 1.95 & 147 & 6.9 & 20.1 & 129 & 79.2 & 4.48 \\
\hline May & 15.5 & 26 & 2.00 & 147 & 4.9 & 16.6 & 197 & 133.6 & 3.56 \\
\hline June & 14.6 & 24.2 & 2.01 & 112 & 4.7 & 16 & 170 & 112 & 3.08 \\
\hline August & 14.3 & 24 & 2.12 & 104 & 2.5 & 13.1 & 120 & 72 & 2.52 \\
\hline September & 14.6 & 25.8 & 2.22 & 130 & 5 & 17 & 163 & 106.4 & 3.23 \\
\hline October & 14.5 & 26.2 & 2.15 & 130 & 6.4 & 18.5 & 96 & 52.8 & 3.51 \\
\hline November & 14.6 & 26.6 & 1.98 & 112 & 7 & 18.3 & 31 & 8.6 & 3.55 \\
\hline December & 14.8 & 26.6 & 1.86 & 104 & 8 & 19.1 & 19 & 1.4 & 3.63 \\
\hline
\end{tabular}




\subsection{Rainfall and Temperature Profiles}

A variation of rainfall at the selected station of Bure within the project area is shown in Figures 3, 4 and Table 1. The rain fall distribution of the 'woreda' is characterized by uni-modal one that lasts for three months from May to September. The average annual rainfall distribution is 1195 $\mathrm{mm} / \mathrm{annum}$. Potential evapo-transpiration PET is also related to altitude. At Bure and its surrounding of the project area mean annual PET is $1300.14 \mathrm{~mm}$, the daily PET is over the rainfall during dry seasone (November, December, January, February and March). The red pepper is grown as rainfed crop in areas with $850-1200 \mathrm{~mm}$ annual rainfall. Heavy rainfall leads to poor fruit set and rotting of fruits and dry spell results in substantial reduction of yield [24].

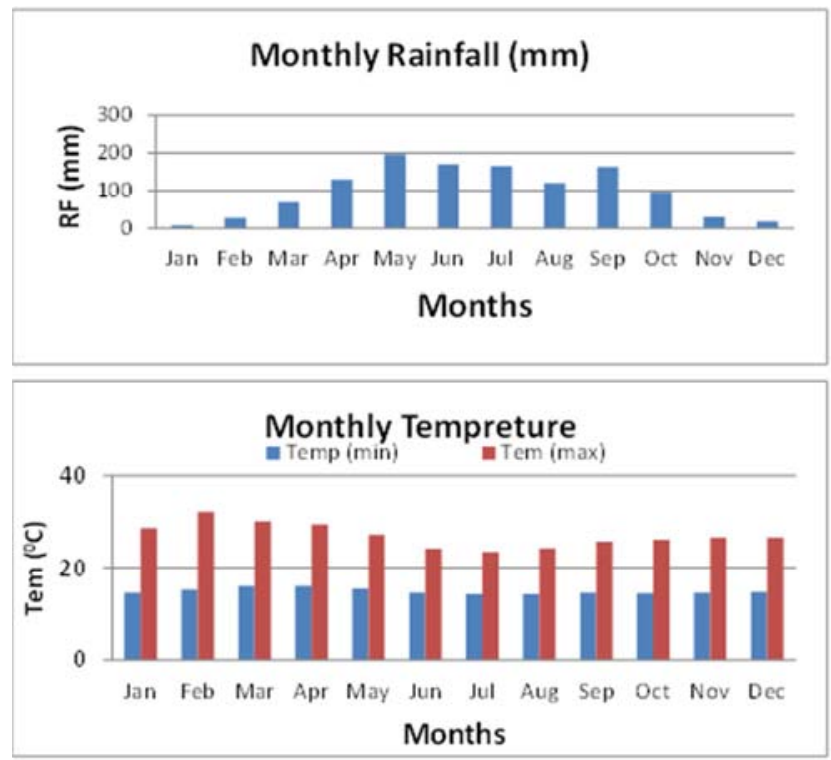

Figure 3. Monthly climatic profiles of rainfall.

Temperature is an important element of weather in crop production. Several factors influence the temperature of an area including latitude, altitude, distance from large water bodies and direction of prevailing winds. Maximum temperature usually occurs during daytime and the minimum during the night. As indicated below, the temperature of the project area ranges between $14^{\circ} \mathrm{C}$ and $32^{\circ} \mathrm{C}$ with the maximum annual temperature of $32^{\circ} \mathrm{C}$. Mean monthly maximum and minimum profiles of temperature show only a slight variation from February to January to May and August to January. The climatic condition at the time of flowering and fruit setting has a significant effect on yield of red pepper. This crop requires an optimal day and night temperatures of $20-30^{\circ} \mathrm{C}$ and $15-20^{\circ} \mathrm{C}$ respectively. Red pepper is very sensitive to low and high temperatures, night temperature below $15^{\circ} \mathrm{C}$ and day temperature above $32^{\circ} \mathrm{C}$ for extended periods retard growth and development, inhibit fruit setting and finally decreases yield [24].

\subsection{Sunshine, Wind Speed and Relative Humidity Profiles}

Solar radiation provides nearly all of the energy that reaches the earth's surface. Daily sunshine hour's duration is thus a factor that determines radiation and the potential evapotranspiration. The longer the sunshine hour is, the more evapotranspiration occurs [15]. The mean monthly sunshine hour of the study was about 6 hours. The maximum was recorded in December (8hrs) followed by January and February. The duration was shorter during the wet season (August) when high humidity and cloudy sky prevails in the area. The daily sunshine hour (SH), Day length (DL) and SF (sunshine fraction) were represented by figure 5 indicating that daily day length of the study area was about 11.5.

The mean monthly wind speed $(\mathrm{km} / \mathrm{hr})$ and relative humidity (hPa) was 5.25 and 15.45 respectively. However, the maximum was recorded in April (6.28) and September (17.77) followed by March and August whereas the minimum was recorded in December (4.39) and February (12.16) as it is represented by figure 6. Generally, high temperature associated with low relative humidity at the time of flowering increases transpiration resulting in abscission of buds, flowers, and resulting in small fruits.
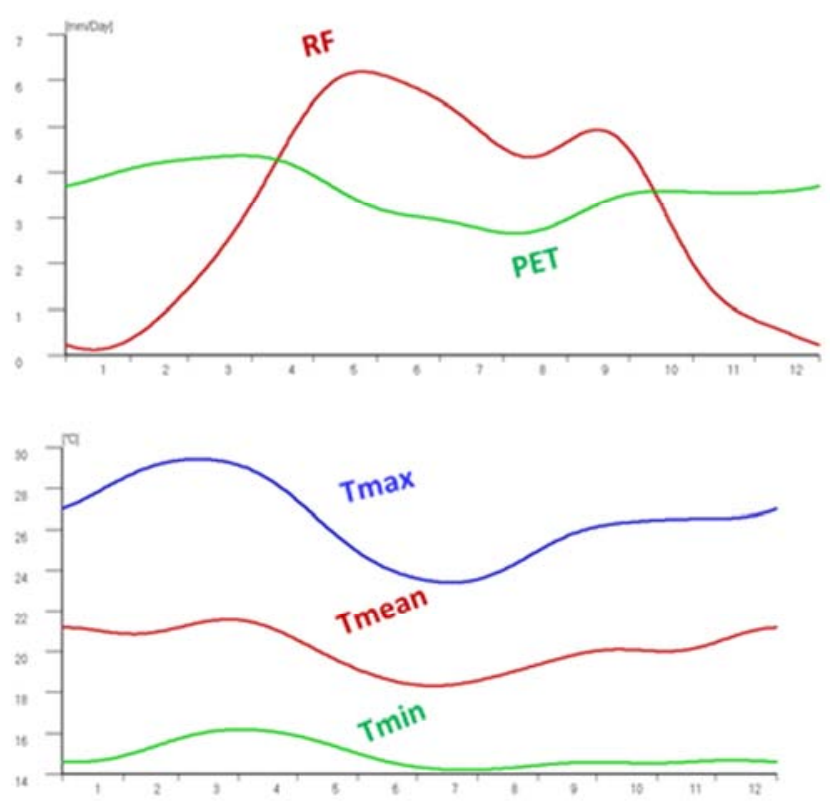

Figure 4. Monthly climatic profiles of temperature.

\subsection{Reference Evapotranspiration}

Reference Evapotranspiration (ET) is the combined process by which water is transferred from the earth's surface to the atmosphere $[4 ; 13]$. It includes evaporation of water from soil and vegetation surfaces plus transpiration of water through plant tissues. It depends on the availability of water in the soil, evaporative demand of the atmosphere, crop density and cover and stage of growth. The maximum ET, given abundant water, is the Potential Evapotranspiration (PET). The PET is calculated by the Penman method as 
outlined by FAO's CROPWAT model. The input data are Temperature, Relative Humidity, Wind Speed, and Sunshine duration. The average monthly PET computed from the available data ranges from a minimum $92.5 \mathrm{~mm}$ during June followed by August and July whereas a maximum of 129.2 mm during April and followed by January and February; the annual average being $108.27 \mathrm{~mm}$ (Table 2 and Figures $3 \& 4$ ).

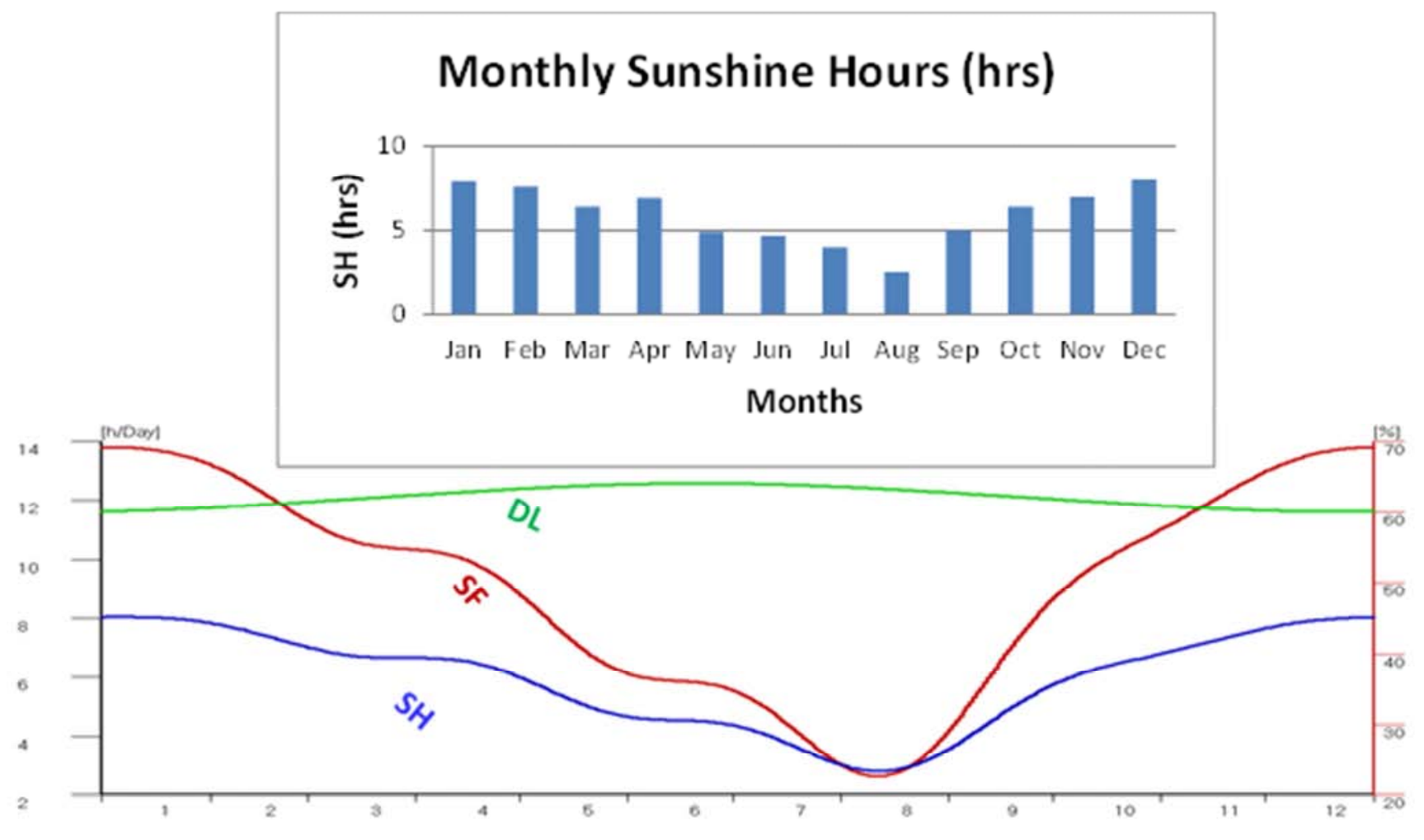

Figure 5. Monthly profiles of sunshine hours.

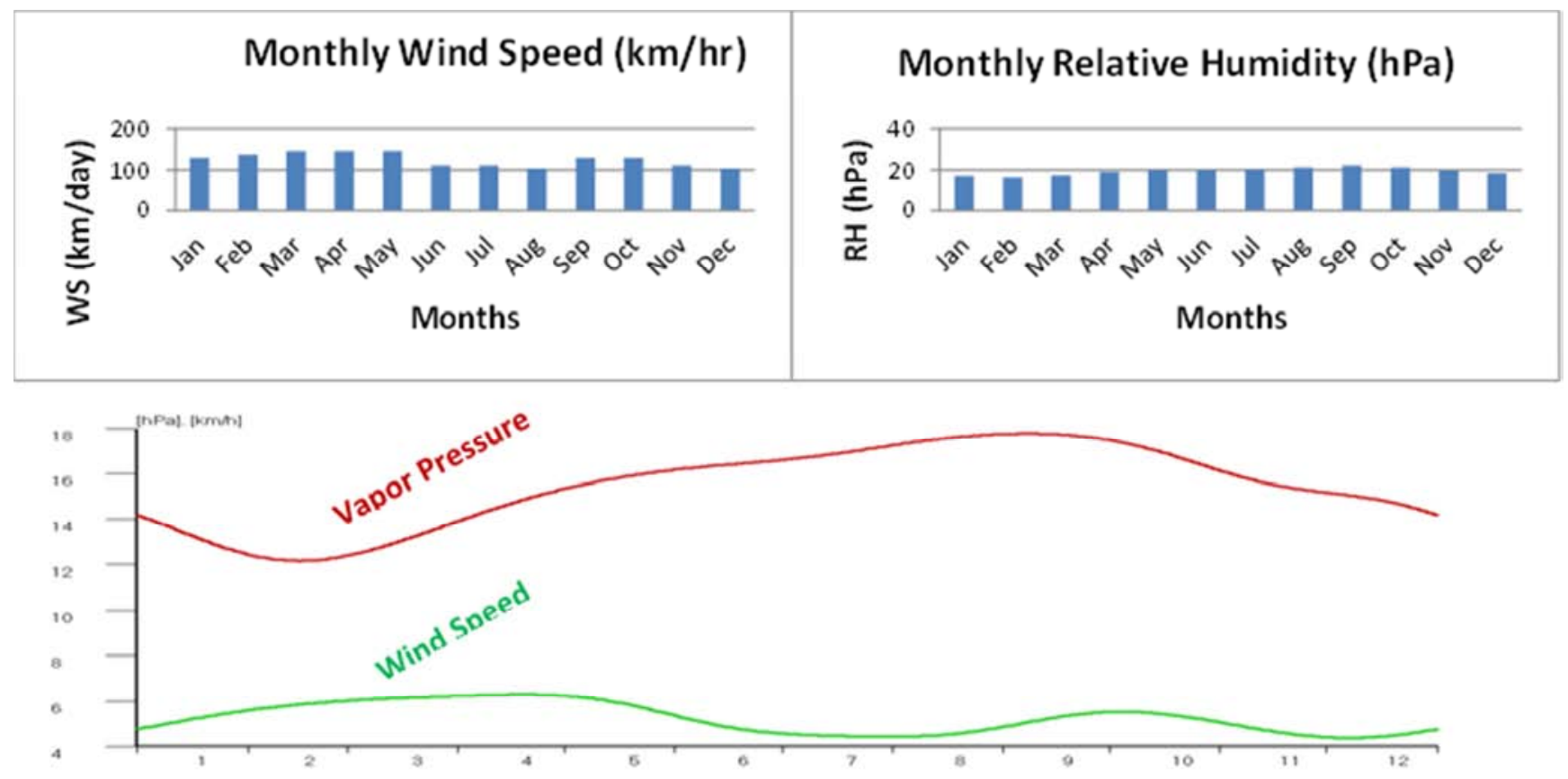

Figure 6. Monthly profiles of wind speed and relative humidity.

Table 2. Average Monthly \& Annual PET.

\begin{tabular}{|c|c|c|c|c|c|c|c|c|c|c|c|c|c|}
\hline ET & Jan & Feb & Mar & Apr & May & Jun & Jul & Aug & Sep & Oct & Nov & Dec & Year \\
\hline$(\mathrm{mm}) /$ day & 3.9 & 4.8 & 4.4 & 4.5 & 3.4 & 3.1 & 2.7 & 2.4 & 3.2 & 3.4 & 3.6 & 3.5 & 3.6 \\
\hline$(\mathrm{mm}) / \mathrm{month}$ & 120.3 & 134.7 & 135.9 & 134.4 & 106.8 & 92.4 & 84.3 & 75.6 & 96.9 & 105.3 & 106.5 & 108.9 & 99.6 \\
\hline
\end{tabular}




\section{Irrigation Agronomy}

\subsection{Crop Water Requirement}

Crop production covers a wide range of crops which include both cash and food crops. The crops grown include: maize; finger millet, pepper, tef, wheat, faba bean, potato, barley and niger seed under rain fed. While potato, pepper, barley, shallot, garlic, coffee and banana are the major crops grown in the 'woreda' under irrigation and other perennial and annual horticultural crops also cultivated using irrigation. Chickpea and fieldpea also cultivated on vertisol using residual moisture after teff. Generally production practices are poor; for instance the use of unimproved, low yielding cultivars is common. Most annual crops are established by broadcast method while row planting is adopted for maize and pepper only.

Based on the prevailing resources of the project area and the objectives of the project, the agronomy study recommended the following crops to be grown in the project:

1. Spices: Red pepper (major crop), black and white cumin and garlic.

2. Herbs: Rosemary and Moringa

3. Pulses: Chickpea and Field pea.

\subsection{Major Crops Cropping Pattern and Calendar of Farming System}

The irrigation agronomy plan envisages some of the mandated crops for a general planning in the estimation of water demand on annual basis. The proposed crops are grouped into three main categories major crop (Red Pepper), others Spices (black and white cumin and garlic), Herbs (Rosemary and Moringa) and Pulses (chickpea \& field pea). The cropping pattern indicated here only serves as a guide that will eventually leads to the project's water requirement and cost/benefit analysis.

Table 3. Annual cropping pattern and cropping calendar for project area.

\begin{tabular}{|c|c|c|c|c|c|c|c|c|c|c|c|c|c|c|c|}
\hline Crops & Area (ha) & Jan & Feb & Mar & Apr & May & Jun & Jul & Aug & Sep & Oct & Nov & Dec & Develop. Stage & $\begin{array}{l}\text { Total G. } \\
\text { Cycle }\end{array}$ \\
\hline \multicolumn{16}{|l|}{ Dry Season } \\
\hline Red Pepper & 200 & & & & & & & & & & & & & $30,35,40,20$ & 125 \\
\hline Rosemary & 40 & & & & & & & & & & & & & $60,90,105,110$ & 365 \\
\hline Herbs-Moringa & 10 & & & & & & & & & & & & & $90,90,90,95$ & 365 \\
\hline \multicolumn{16}{|l|}{ Wet Season } \\
\hline Feildpea & 70 & & & & & & & & & & & & & $2530,40,15$ & 110 \\
\hline Black Cumin & 30 & & & & & & & & & & & & & $25,30,40,20$ & 115 \\
\hline White Cumin & 10 & & & & & & & & & & & & & $25,30,40,20$ & 115 \\
\hline Garlic & 30 & & & & & & & & & & & & & $30,40,45,20$ & 135 \\
\hline Total & 250 & & & & & & & & & & & & & & \\
\hline
\end{tabular}

\subsection{Crop Water Requirements}

The estimation of crop water requirements needs the analysis of climatic data and recommended agronomic practice of each irrigation scheme. The effect of climate on crop water requirement was given by the reference crop evapotranspiration $\left(\mathrm{ET}_{\mathrm{o}}\right)$ that was analysed using the penman method [4]. The actual amount of water used by a crop, or crop evapotranspiration $\left(\mathrm{ET}_{\mathrm{c}}\right)$, was related to $\mathrm{ET}_{\mathrm{o}}$ by crop coefficient $\mathrm{k}_{\mathrm{c}}$ so that

$$
\mathrm{ET}_{\mathrm{c}}=\mathrm{k}_{\mathrm{c}} * \mathrm{ET}_{\mathrm{o}}
$$

Crops characteristics $\left(\mathrm{k}_{\mathrm{c}}\right)$ values were obtained from [12]. Dry season as well as wet season supplementary crop water requirements $\left(\mathrm{ET}_{\mathrm{c}}\right)$ are given in Appendix I. Climatic data and reference crop evapotranspiration (ETo) for the project area is analysed in detail is explained under climate and hydrology component. The table below summarizes climatic data as well as ETo, which was used for the determination of Crop Water Requirement (CWR) following the procedure on $[12 ; 16]$. The crop data used for calculating the crop water requirements of the project area is summarized in the following table, Table 4. The CWR for each crop has been determined and presented as Annex- I. The net water requirements in $\mathrm{mm} /$ day and $1 / \mathrm{s} /$ ha for the proposed cropping pattern are given in a tabular form given. From the table, it can be seen that the maximum net water requirements occur in the month of February, when they reach a value of 199.561/s. Net and Gross Water Requirements for the proposed cropping are calculated based on $65 \%$ overall efficiency for surface irrigation systems. The table in Annex-I shows that a total volume of $1.704 \mathrm{Mm}^{3}$ will be needed, annually; the range being from $0.003 \mathrm{Mm}^{3}$ in June to $0.516 \mathrm{Mm}^{3}$ in Februarys.

During the wet season the daily rainfall is often adequate to support the crop growth. However, there are frequent periods of rainfall shortage, in which the crop would die, or crop yields would be substantially depressed due to moisture stress. Supplemental irrigation is, therefore, the application of a limited amount of water to the crop when the rainfall fails to provide sufficient water for plant growth, to increase and stabilize yields. The timing of supplemental irrigation is determined during the critical stages of crop growth and these critical growth periods are mainly during the beginning and end of the rainy seasons. 
Table 4. Cropping parameters for water demand analysis.

\begin{tabular}{|c|c|c|c|c|c|c|c|c|c|c|c|}
\hline \multirow{2}{*}{ Crop } & \multicolumn{2}{|c|}{ Planting Date } & \multirow{2}{*}{$\begin{array}{l}\text { Growing Period } \\
\text { (Days) }\end{array}$} & \multicolumn{4}{|c|}{ Days of Growth Stages } & \multicolumn{4}{|c|}{ Crop Coefficient } \\
\hline & Month & Day & & D1 & D2 & D3 & D4 & Ke1 & Kc2 & Kc3 & Ke4 \\
\hline \multicolumn{12}{|l|}{ Dry Season } \\
\hline Red Pepper & 12 & 1 & 125 & 20 & 35 & 45 & 30 & 0.5 & 0.85 & 1.05 & 0.7 \\
\hline Rosmery & 8 & 1 & 365 & 60 & 90 & 105 & 110 & 0.35 & 0.75 & 1.05 & 0.75 \\
\hline Moringa & 6 & 1 & 365 & 90 & 90 & 90 & 95 & 0.3 & 0.75 & 1.2 & 0.65 \\
\hline \multicolumn{12}{|l|}{ Wet Season } \\
\hline Checkpea & 8 & 15 & 115 & 25 & 30 & 40 & 20 & 0.4 & 0.95 & 1.15 & 0.35 \\
\hline Feildpea & 8 & 15 & 110 & 25 & 30 & 40 & 15 & 0.4 & 0.95 & 1.15 & 0.35 \\
\hline Black Cumin & 8 & 1 & 115 & 25 & 30 & 40 & 20 & 0.3 & 0.7 & 0.95 & 0.25 \\
\hline White Cumin & 8 & 1 & 115 & 25 & 30 & 40 & 20 & 0.3 & 0.7 & 0.95 & 0.25 \\
\hline Garlic & 7 & 1 & 135 & 30 & 40 & 45 & 20 & 0.7 & 0.95 & 1.0 & 0.7 \\
\hline
\end{tabular}

\section{Conclusion and Recommendation}

The implementation such integrated irrigation development project will bring a number of economic and social benefits. These include improved economic and nutritional status through increased agricultural production and productivity of red pepper, improvement income and market access for local producer, creation of employment opportunities and farming skill development. The Jabi Tehana woreda irrigation development is found to be technically feasible based on the field data analysis and previously studied documents. On the Jabi plain, gravity irrigation scheme with 300 ha with good suitability of soil and enough availability of surface water.

It is recommended that this project should be compared with other projects in the same sector in the project area, preferably after they also have been studied in a compatible manner. Projects that can take advantage of pre-existing infrastructure and services may appear economically preferable, but the economic criteria are not the only ones, and in the development of a country like Ethiopia.

\section{Conflicts of Interest}

The authors declare there is no conflict of interest.

\section{Acknowledgements}

We would like to thank the West Gojjam Zonal offices, Jabi Tehnan woreda, Bure woreda, Womberima woreda for their cooperation during feasibility and data collection period. Our special thanks go to zonal investment office and manager of Bure integrated industrial park for their support in the course of the study.

\section{Appendix: Detail Determination of Irrigation Duty for Each Target Commodity of the Command Area}

Crop Water Requirements - Dry Season (Irrigated)

(Application Efficiency 65\%)

\begin{tabular}{|c|c|c|c|c|c|c|c|c|c|c|c|c|c|}
\hline \multirow{2}{*}{ Crop-Red Pepper } & \multicolumn{2}{|c|}{ Area (ha) } & \multirow{2}{*}{$\begin{array}{l}200 \\
\text { Mar }\end{array}$} & \multirow{2}{*}{$\begin{array}{l}\text { P Date } \\
\text { Apr }\end{array}$} & \multicolumn{2}{|c|}{ 1- Dec. } & \multirow[b]{2}{*}{ Jul } & \multirow[b]{2}{*}{ Aug } & \multirow[b]{2}{*}{ Sep } & \multirow[b]{2}{*}{ Oct } & \multirow[b]{2}{*}{ Nov } & \multirow[b]{2}{*}{ Dec } & \multirow[b]{2}{*}{ Total } \\
\hline & Jan & Feb & & & May & Jun & & & & & & & \\
\hline Crop Factor $(\mathrm{Kc})$ & 0.81 & 1.04 & 1.01 & 0.90 & & & & & & & & 0.60 & \\
\hline ETo (mm) & 120.3 & 134.7 & 135.9 & 134.4 & 106.8 & 92.4 & 84.3 & 75.6 & 96.9 & 105.3 & 106.5 & 108.90 & 1302 \\
\hline $\mathrm{ETc}(\mathrm{mm})$ & 102.2 & 129.4 & 141.4 & 16.2 & & & & & & & & 68.30 & 457.5 \\
\hline $85 \%$ Dependable Rainfall (mm) & 15.3 & 23.6 & 50.4 & 58.9 & 60.4 & 69.7 & 203.6 & 183.2 & 98.7 & 38.4 & 13.1 & 9.50 & \\
\hline Effective Rainfall (ER) (mm) & -0.82 & 4.16 & 20.24 & 25.34 & & & & & & & & -4.30 & \\
\hline Net Irrigation Requirement (mm) & 103.02 & 125.24 & 121.16 & -9.14 & & & & & & & & 72.60 & \\
\hline Field Irrigation Requirement (mm) & 158.49 & 192.68 & 186.40 & -14.06 & & & & & & & & 111.69 & \\
\hline Field Irrigation Requirement (mm/day) & 5.11 & 6.88 & 6.01 & -0.47 & & & & & & & & 3.72 & \\
\hline Crop Water Needs (1/s/ha) & 0.59 & 0.80 & 0.70 & -0.05 & & & & & & & & 0.43 & \\
\hline Flow $(1 / \mathrm{s})$ & 118.61 & 159.65 & 139.50 & -10.87 & & & & & & & & 86.38 & \\
\hline
\end{tabular}

\begin{tabular}{|c|c|c|c|c|c|c|c|c|c|c|c|c|c|}
\hline \multirow{2}{*}{ Crop-Rosemary } & \multicolumn{2}{|r|}{ Area } & \multirow{2}{*}{$\begin{array}{l}40 \\
\text { Mar }\end{array}$} & \multirow{2}{*}{$\begin{array}{l}\text { P Date } \\
\text { Apr }\end{array}$} & \multicolumn{9}{|l|}{ 1-Jun } \\
\hline & Jan & Feb & & & May & Jun & Jul & Aug & Sep & Oct & Nov & Dec & Total \\
\hline Crop Factor $(\mathrm{Kc})$ & 1.20 & 1.05 & 0.98 & 0.84 & 0.81 & 0.25 & 0.68 & 0.41 & 0.80 & 0.93 & 1.03 & 1.10 & \\
\hline ETo (mm) & 120.30 & 134.70 & 135.90 & 134.40 & 106.80 & 92.40 & 84.30 & 75.60 & 96.90 & 105.30 & 106.50 & 108.90 & 1302.00 \\
\hline $\mathrm{ETc}(\mathrm{mm})$ & 126.32 & 132.01 & 113.76 & 108.60 & 86.30 & 23.10 & 57.38 & 30.73 & 77.52 & 97.66 & 109.70 & 119.79 & 1082.86 \\
\hline 85\% Dependable Rainfall (mm) & 15.30 & 7.26 & 13.42 & 22.52 & 12.33 & 25.21 & 130.23 & 135.58 & 64.80 & 6.05 & 2.71 & 3.37 & \\
\hline Effective Rainfall (ER) (mm) & -0.82 & -5.64 & -1.95 & 3.51 & -2.60 & 5.13 & 68.14 & 71.35 & 28.88 & -6.37 & -8.37 & -7.98 & \\
\hline Net Irrigation Requirement (mm) & 127.14 & 137.65 & 115.71 & 105.09 & 88.90 & 17.97 & -10.76 & -40.62 & 48.64 & 104.03 & 118.07 & 127.77 & \\
\hline
\end{tabular}




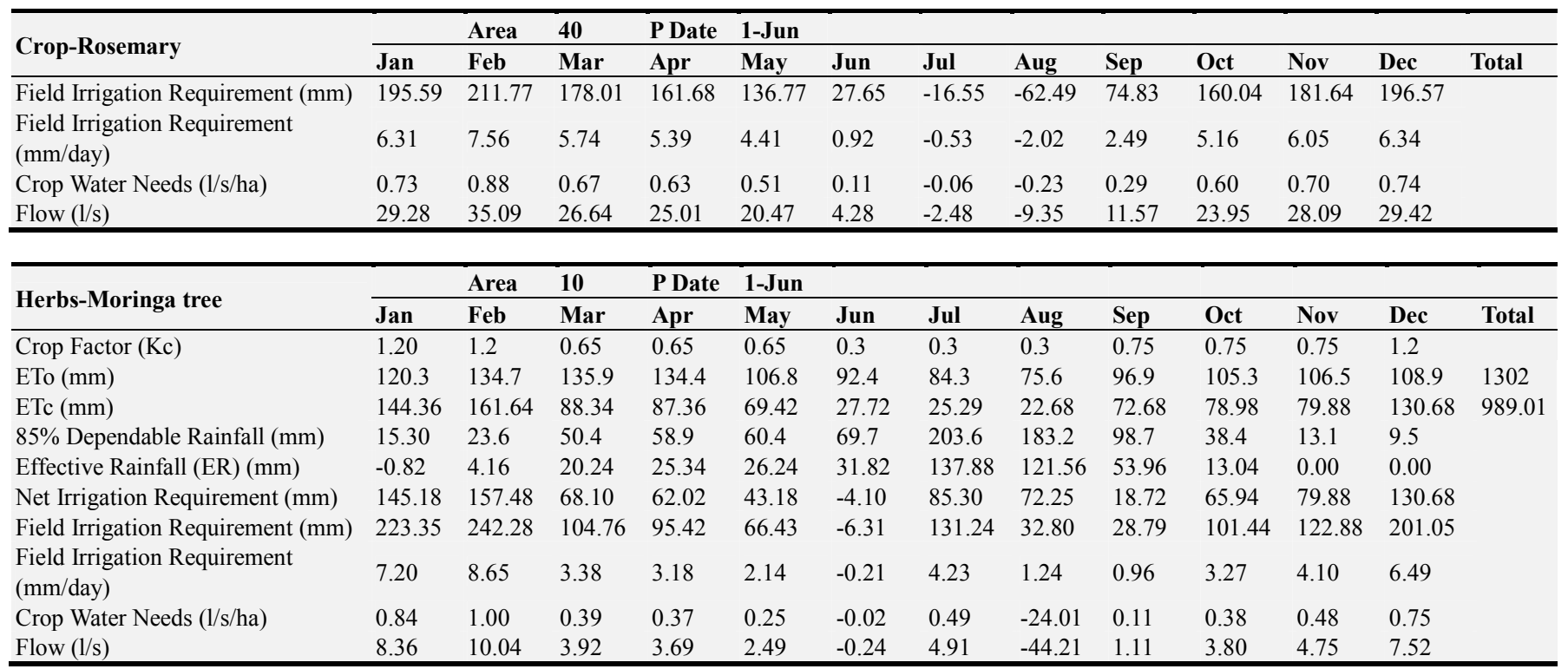

Crop Water Requirements - Wet Season (rainfed-supplemental irrigation)

(Application Efficiency 65\%)

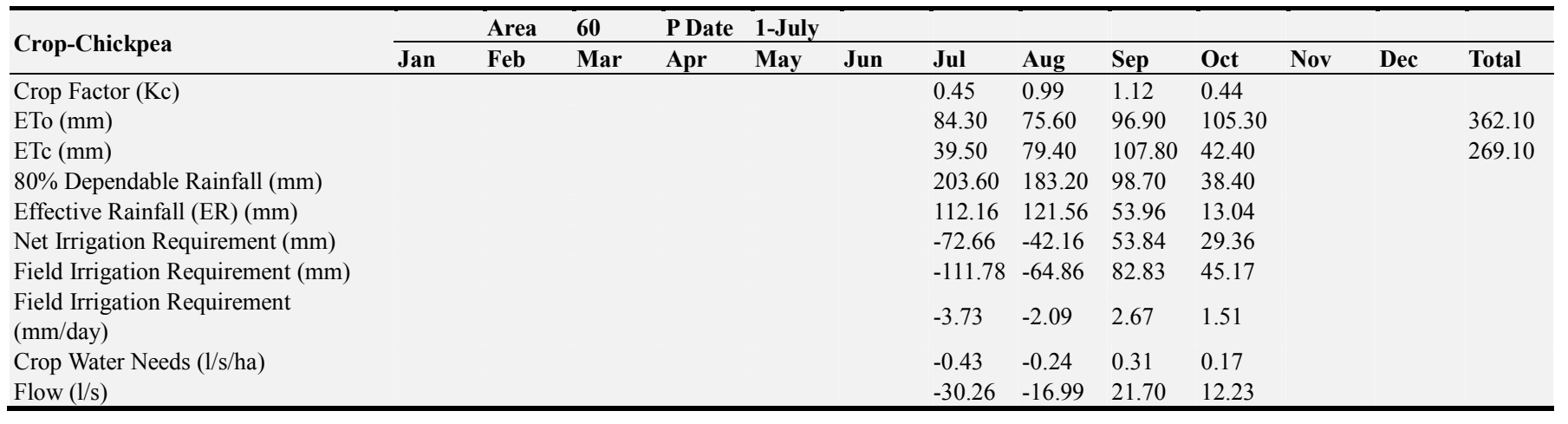

\begin{tabular}{|c|c|c|c|c|c|c|c|c|c|c|c|c|c|}
\hline \multirow{2}{*}{ Crop-Feildpea } & \multicolumn{2}{|r|}{ Area } & \multirow{2}{*}{$\begin{array}{l}70 \\
\text { Mar }\end{array}$} & \multirow{2}{*}{$\begin{array}{l}\text { P Date } \\
\text { Apr }\end{array}$} & \multicolumn{2}{|l|}{ 1-July } & \multirow[b]{2}{*}{ Jul } & \multirow[b]{2}{*}{ Aug } & \multirow[b]{2}{*}{ Sep } & \multirow[b]{2}{*}{ Oct } & \multirow[b]{2}{*}{ Nov } & \multirow[b]{2}{*}{ Dec } & \multirow[b]{2}{*}{ Total } \\
\hline & Jan & Feb & & & May & Jun & & & & & & & \\
\hline Crop Factor (Kc) & & & & & & & 0.45 & 0.99 & 1.12 & 0.44 & & & \\
\hline ETo $(\mathrm{mm})$ & & & & & & & 84.30 & 75.60 & 96.90 & 105.30 & & & 362.10 \\
\hline $\mathrm{ETc}(\mathrm{mm})$ & & & & & & & 39.50 & 79.40 & 107.80 & 42.40 & & & 269.10 \\
\hline $80 \%$ Dependable Rainfall (mm) & & & & & & & 203.60 & 183.20 & 98.70 & 38.40 & & & \\
\hline Effective Rainfall (ER) (mm) & & & & & & & 112.16 & 121.56 & 53.96 & 13.04 & & & \\
\hline Net Irrigation Requirement (mm) & & & & & & & -72.66 & -42.16 & 53.84 & 29.36 & & & \\
\hline Field Irrigation Requirement (mm) & & & & & & & -111.78 & -64.86 & 82.83 & 45.17 & & & \\
\hline $\begin{array}{l}\text { Field Irrigation Requirement } \\
(\mathrm{mm} / \text { day })\end{array}$ & & & & & & & -3.73 & -2.09 & 2.67 & 1.51 & & & \\
\hline Crop Water Needs (1/s/ha) & & & & & & & -0.43 & -0.24 & 0.31 & 0.17 & & & \\
\hline Flow $(1 / \mathrm{s})$ & & & & & & & -30.26 & -16.99 & 21.70 & 12.23 & & & \\
\hline
\end{tabular}

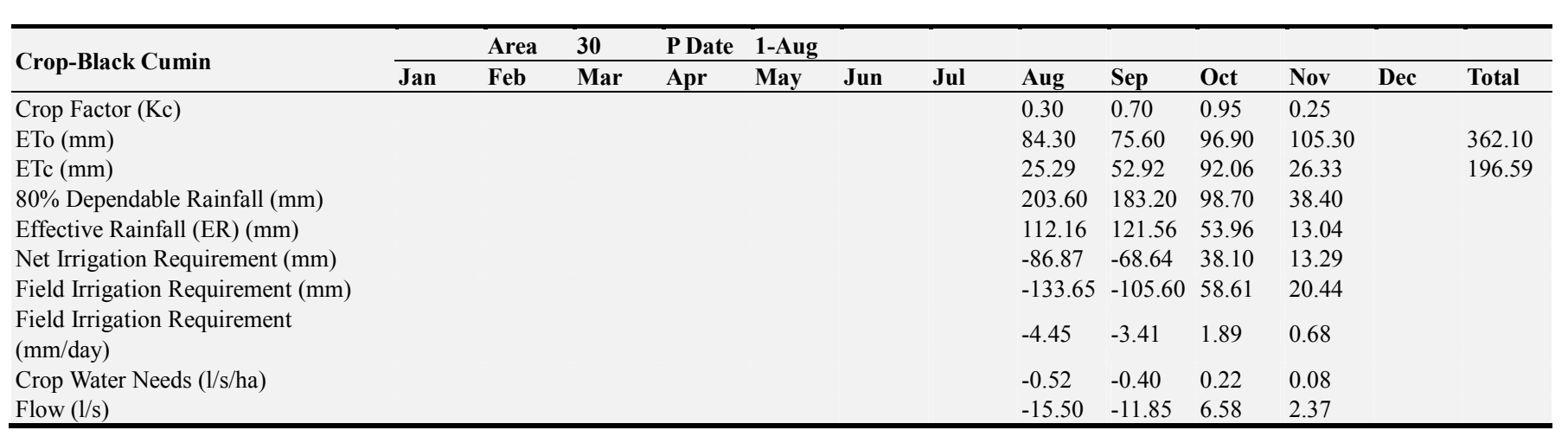




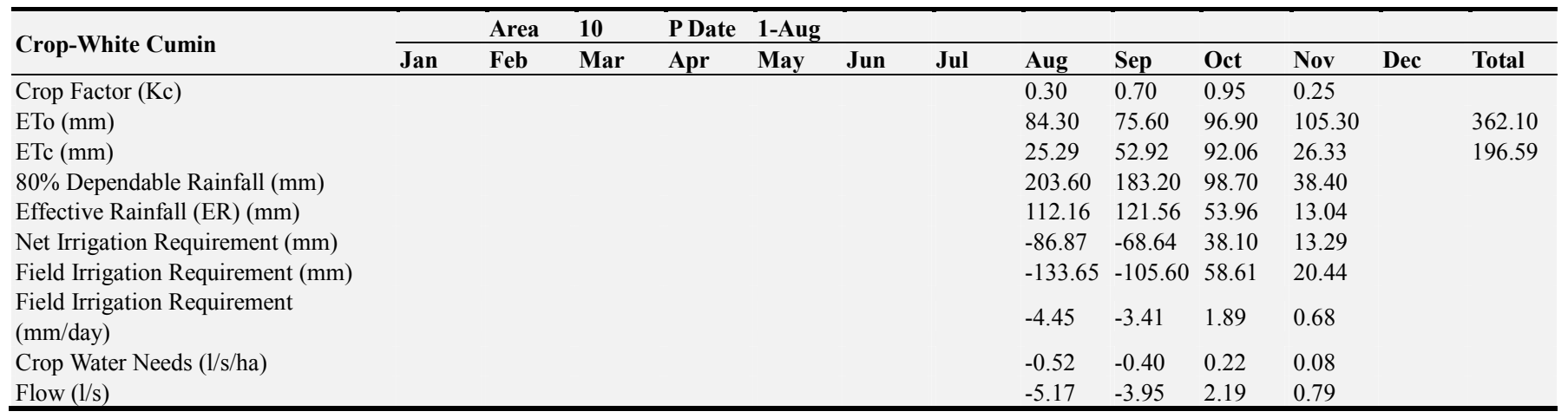

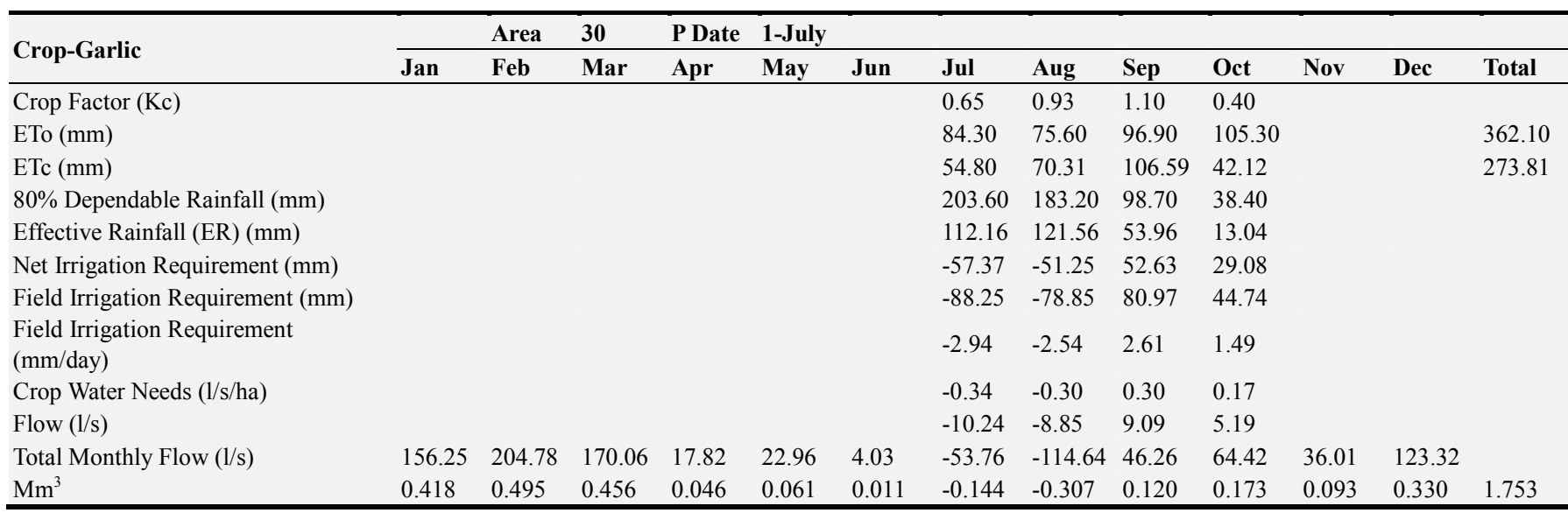

Crop Water Requirements - Dry Season

(Application Efficiency 65\%)

Effective Rainfall $=0.8 * \mathrm{P}-25$ If $\mathrm{P}>75 ;=0.6 * \mathrm{P}-10$ If $\mathrm{P}<75$

Net Irrigation Requirement=ETc - Effective Rainfall

Field Irrigation Requirement $=($ Net Irrigation Requirement $) /($ Application Efficiency 65\%).

Crop Water Needs $(1 / \mathrm{s} / \mathrm{ha})=\mathrm{mm} /$ day*0.116

Flow $(1 / \mathrm{s})=1 / \mathrm{s} / \mathrm{ha} *$ Area $(\mathrm{ha})$

\section{References}

[1] ACP (Agricultural Commodities Programme), (2010). Spice sub-sector strategy for Ethiopia submitted to the government of Ethiopia by the Spice Sector Strategy Coordinating Committee.

[2] Ahmed, H. (2002). Assessment of Spatial Variability of Some Physicochemical Characteristics of Soils under Different Elevations and Land Use Systems in the Slopes of Mount Chilalo. M. Sc. Thesis, Alemaya University, Ethiopia, 104 pp.

[3] Ali, A., Jafar, Z., Parisa, A. i, Mohamed, R. N., \& Siamak, S. (2008). Land suitability evaluation of Bilverdy research station for wheat, barley, alfalfa, maize and safflower. Soil and Water Research. 3: S81-S88.

[4] Allen, R. G., Pereira, L. S., Raes, D. \& Smith, M. 1998. Crop evapotranspiration-Guidelines for computing crop water requirements.

[5] AQUASTAT. (2014). Area Equipped for Irrigation; Prepared by AQUASTAT, FAO's Global Information System; Food and Agriculture Organization of the United Nations: Roma, Italy.

[6] Awulachew, S. B.; Yilma, A. D.; Loulseged, M.; Loiskandl, W.; Ayana, M.; Alamirew, T. (2007). Water Resources and Irrigation Development in Ethiopia. Colombo, Sri Lanka:
International Water Management Institute. 66p. (IWMI Working Paper 123).

[7] Belay, T. (1996). Characteristics and landscape relationships of Vertisols and vertic Luvisols of Melbe Tigray in Ethiopia. SINET: Ethiopian Journal of Science. 19 (1): 93-115.

[8] Birru, Y., \& Heluf, G. (2003). Kinetics of phosphorus for some selected soils of the northwestern highlands of Ethiopia. In: Tilahun Amede and Eylachew Zewdie (eds.), Challenges of land degradation to agriculture in Ethiopia. Proceeding of the 6th ESSS conference. Ethiopian Society of Soil Science.

[9] Bray, R. H., \& Kurtz, L. T. (1945). Determination of total organic and available forms of phosphorus in soils. Soil Society. 59: 39-45.

[10] Brady, N. C. and Weil, R. (2002). The Nature and Properties of Soils. 13th edition. Singapore, Pearson Education. 976pp.

[11] Dagnaygebaw Goshme, Tariku Ayel, Factors Affecting Production and Marketing of Spices in Ethiopia: A Review. International Journal of Forestry and Horticulture 2019, 5 (2): 14-18.

[12] FAO Irrigation and drainage paper 56. FAO, Rome, 300, D05109.

[13] FAO 1997. Irrigation Potential in Africa. A Basin Approach. Land and Water Bulletin N. 4. 
[14] FAO (2006). Guidelines for Soil Description. Fourth edition. Food and Agriculture Organization of the United Nations. 97pp. 5 Part III, FAO, Rome, Italy.

[15] FAO, 2001, Irrigation Water Management: Irrigation Methods, Rome, Italy.

[16] FAO, 1998. Guidelines for computing Crop Water Requirements, Irrigation and Drainage Paper, No. 56. Rome, Italy.

[17] Ganole, K. 2010. GIS-based surface irrigation potential: Assessment of river catchments for irrigation development in Dale Woreda, Sidama Zone, SNNP. Haramaya University.

[18] Habtewold, K., Demes, F., Tewodros, L., Dejene, B., Haimanot, M., \& Wakjira, G. (2017). Seed spices production guideline: Ethiopian institute of agricultural research.

[19] Hailegebriel, S. 2007. Irrigation Potential Evaluation And Crop Suitability Analysis using GIS and Remote Sensing Technique in Beles sub Basin, Beneshangul Gumez region. aau.

[20] Hagos, F.; Makombe, G.; Namara, R. E.; Awulachew. S. B. (2007). Does Access to Small Scale Irrigation Promote Market Oriented Production in Ethiopia? Submitted to Agricultural Economics. Forth coming.

[21] International Trade Centre, 2010. Spice Sub-Sector Strategy for Ethiopia. Addis Ababa, Ethiopia.

[22] Landon, J. R. (1991). Booker Tropical Soil Manual, a hand book for Soil Survey and Agricultural Land Evaluation in the Tropics and Subtropics. Longman, 474p.

[23] Lipton, M.; Litchfield, J.; Faures, J-M. (2003). The Effects of Irrigation on Poverty: A Framework for Analysis. Water Policy 5: 413-427.

[24] Mahoo H, Radeny M, Kinyangi J, Cramer L, eds. 2013. Climate change vulnerability and risk assessment of agriculture and food security in Ethiopia: Which way forward? CCAFS Working.

[25] Paper no. 59. CGIAR Research Program on Climate Change, Agriculture and Food Security (CCAFS). Copenhagen, Denmark. Available online at: www.ccafs.cgiar.org.

[26] Mekonnen G. (2015). Characterization of Agricultural Soils in Cascape Intervention Woredas of Amhara Region, BDUCASCAPE working paper 12, Bahir Dar, Ethiopia.

[27] MoFED (Ministry of Finance and Economic Development). 2006. Ethiopia: Building on Progress. A Plan for Accelerated and Sustained Development to End Poverty (PASDEP).
(2005/06-2009/10). Volume I: Main Text. Ministry of Finance and Economic Development (MoFED). September, 2006. Addis Ababa. 229pp.

[28] MoWR (Ministry of Water Resources). 2002. Water Sector Development Programme 2002-2016. Irrigation Development Program, Main report. MoWR, Addis Ababa, Ethiopia. 142pp.

[29] Munsell Colour Company (2009). Munsell Soil Colour Chart. 2009 revised edition. Macbeth Division of Kollmorgen Corporation, Baltimore, Maryland, USA.

[30] Nigusie G., 2020. Assessment of surface water resource and irrigable land potential in Amhara region, Ethiopia: Acase study of Jabi Tehnan Woreda, MSc. Dissertation, Hydraulic and water resource Engineering. Bahir Dar University.

[31] Shimeles, D., Mohammed, A., \& Abayneh, E. (2006). Characterization and Classification of the Soils of TenochaWenchancher Microcatchment in Southwest Shewa. M. Sc. Thesis, Alemaya University, 111 pp.

[32] Soil Survey Staff (2010). Keys to Soil Taxonomy: 11th Edition, United States Department of Agriculture/Natural Resources Conservation Service, USA. 338pp.

[33] Suhardiman, D.; Giordano, M. Is there an alternative for irrigation reform? World Dev. 2014, 57, 91-100.

[34] Tekalign Mamo, Abiye Astatke, K L Srivastava and Asgelil Dibabe (eds). 1993. Improved management of Vertisols for sustainable crop - livestock production in the Ethiopian highlands: ISBN 92-9053-269-6, Synthesis report 1986-92. Technical Committee of the Joint Vertisol Project, Addis Ababa, Ethiopia.

[35] Tiru Tesfa; Wondimu, B.; Arega, G.; Hassen, B. (2017). Spice Production, Marketing, and Utilization in South Wollo, Ethiopia. East African Journal of Sciences. Volume 11 (1): 2736.

[36] Vijayalaxmi, H. \& Sreepada, H. (2014). An economic overview of ginger production in Ethiopia. International Journal of Science and Research, 3 (12), 2052-2054.

[37] World Bank. 2006. Managing Water Resources to Maximize Sustainable Growth: A World Bank Water Resource Assistance Strategy for Ethiopia. Agriculture and Rural Development Department, World Bank.

[38] Yihenew, G. (2002). Selected chemical and physical characteristics of soils of Adet research centre and its testing sites in Northwestern Ethiopia. Ethiopian Journal of Natural Resource. 4 (2): 199-215. 